\title{
COVID-19 with Multiple Bacterial Co-infections: A Case Report
}

\author{
Sadia Saber, Samia Rashna Ahmed, Naz Yasmin, Mohammed Tarek Alam, Abdul Basit Ibne Momen, \\ Mohammad Monower Hossain, and Rafa Faaria Alam
}

\section{ABSTRACT}

Coronavirus disease 2019 (COVID-19) is a contagious disease which was first identified in Wuhan, China in December 2019. Severe acute respiratory syndrome coronavirus 2 (SARS-CoV-2) is responsible for this ongoing pandemic worldwide. COVID-19 itself has a high mortality rate but in addition with bacterial co-infection, the risk of death amplifies much higher. The diagnosis of COVID-19 along with other respiratory coinfections can be a difficult task due to the similarities in their presentations. Here, we present a case of 60 -years-old gentleman who was COVID-19 positive, co-infected with three types of bacterial pathogens, which were Mycobacterium tuberculosis, Enterobacter spp. and Pseudomonas. The patient was isolated and treated according to the pathogens' culture sensitivity reports and was discharged when his condition improved and advised for routine follow-up. The source of the coinfection could not be identified and may have been hospital acquired. Therefore, every hospital should give utmost priority to infection prevention and control (IPC) strategies.

Keywords: COVID-19, Enterobacter, Pseudomonas, SARS-CoV-2.
Published Online: January 7, 2021

ISSN: 2593-8339

DOI: $10.24018 /$ ejmed.2021.3.1.646

Dr. Sadia Saber*

MBBS, FCPS, MRCP (UK), MRCP

(Ireland), MRCP (Glasgow), MACP (USA).

Assistant Professor, Department of

Medicine, Bangladesh Medical College, Dhaka, Bangladesh.

(e-mail: sadiasaber201477@gmail.com)

Dr. Samia Rashna Ahmed

MBBS, Trainee, Department of

Medicine, Bangladesh Medical College, Dhaka, Bangladesh.

Dr. Naz Yasmin

MBBS, FCPS, MS, Assistant Professor, Department of Gynae \& Obs., International Medical College, Dhaka, Bangladesh.

Dr. Mohammed Tarek Alam

MBBS, MD (USA), Professor and Head, Department of Medicine, Bangladesh Medical College, Dhaka, Bangladesh.

Dr. Abdul Basit Ibne Momen

MBBS, MRCP (UK), Registrar, Department of Medicine, Bangladesh Medical College, Dhaka, Bangladesh.

Dr. Mohammad Monower Hossain MBBS, Medical Officer, Department of Medicine, Bangladesh Medical College Hospital, Dhaka, Bangladesh.

Dr. Rafa Faaria Alam

MBBS, Medical officer, Department of Medicine, Bangladesh Medical College Hospital, Dhaka, Bangladesh.

*Corresponding Author

\section{INTRODUCTION}

A rapidly spreading newly recognized pneumonia caused by Severe acute respiratory syndrome coronavirus 2 (SARS-Co-V-2) was first declared in Wuhan (Hubei province), China, on December 2019. Since then, this novel Coronavirus (2019-nCoV) has generated $16 \quad 812755$ confirmed cases including 662095 deaths worldwide as of 30 July, 2020 [1]. People of all over the world are deeply concerned both by the alarming levels of its transmission and severity, and by the alarming levels of inertia. The World Health Organization (WHO) has been evaluating this outbreak around the clock and declared it as a Pandemic condition. SARS-CoV-2 pneumonia has a diverse clinical spectrum ranging from mild to critically ill patients. Significant high mortality rate in COVID-19 has been found due to severe pneumonia and acute respiratory distress syndrome. But it varies according to time, place and person [2]. Covid-19 has become the center of attention of the medical world and the pandemic of 2020 though originating from bats, like other virulent coronavirus $(\mathrm{CoV})$ strains such as severe acute respiratory syndrome corona virus (SARS-CoV) and Middle East respiratory syndrome coronavirus (MERS-CoV) [3]. The main mode of transmission of this novel virus are respiratory droplet particles $(>5-10 \mu \mathrm{m}$ in diameter), aerosols and contact routes [4]. If a symptomatic individual (e.g., coughing or sneezing) comes in a close contact (within 1 meter) with a 
healthy person then there is a great chance for droplet transmission. Fomites in the immediate environment surrounding the infected individual are also responsible for the transmission [5]. Some evidence has also found the presence of COVID-19 infection in the faeces which has led to intestinal infection. However, COVID-19 virus has been cultured from a single stool specimen in only one study so far [6]. No reports have been disclosed regarding its faecaloral transmission till now. Currently, COVID-19 patients remain as the primary source of infection [7]. Studies showed that bacterial co-infection especially with Staphylococcus aureus is a common occurrence with viral respiratory tract infections such as Influenza and is associated with increased morbidity and mortality [8]. However, there are no sufficient resources available mentioning bacterial co-infections in confirmed COVID-19 patients. This pandemic has needed considerable adjustments to healthcare systems and frameworks all over the world. As a result there is rapid modification in the infection control and antimicrobial surveillance programs to combat the current situation effectively. Here, we have presented a complicated case of 60 years old male with confirmed COVID-19 who has also co-infected with Mycobacterium tuberculosis, Enterobacter and Pseudomonas.

\section{CASE Presentation}

A 60 years old diabetic gentleman hailing from Noakhali, Bangladesh admitted to Bangladesh Medical College Hospital on 8th July, 2020 with the complaints of low grade fever, cough with productive sputum and exertional breathlessness for 15 days. On query he mentioned neither any significant past medical history nor any previous history of hospitalization. All of his family members were healthy with no history of contact with tuberculosis (TB) and COVID-19 patients.

On examination, he was tachypnoeic (Respiratory rate 30 breaths/min), tachycardic (heart rate $110 / \mathrm{min}$ ), blood pressure-125/75 $\mathrm{mm}$ of $\mathrm{Hg}$, Temperature: 98 degree Fahrenheit, mildly anemic with no evidence of cyanosis or clubbing. On respiratory system examination bronchial breath sounds and crepitations were found involving the upper and middle zone of right lung. The treatment was started with Amoxicillin and Clavulanic acid, Clarithromycin, anti-diabetic medications and other symptomatic management.

His initial investigations revealed: Hemoglobin (Hb) $8.86 \mathrm{~g} / \mathrm{dl}$, Total white cell count $14 \times 10^{9} / \mathrm{L}$ (neutrophilic leukocytosis), ESR 90mm in $1^{\text {st }}$ hour, CRP $96 \mathrm{mg} / \mathrm{dl}$, Ddimer $2.76 \mathrm{mg} / \mathrm{L}$, Procalcitonin $0.26 \mathrm{ng} / \mathrm{ml}$. X-ray showed homogenous opacity and cavitary lesion mainly involving the upper and middle zone of right lung (Fig. 1).

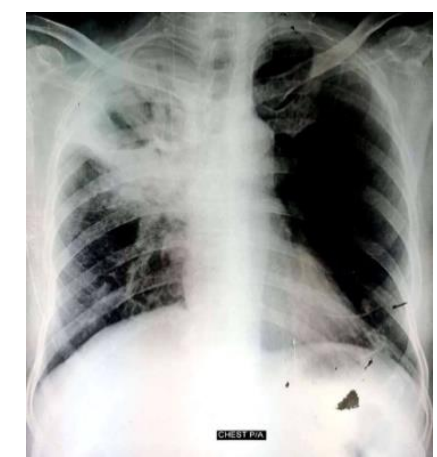

Fig. 1. Homogenous opacity with cavitary lesion in the right lung.

After 48 hours his RT-PCR test for COVID-19 came positive. He was shifted to an isolation room and was given $12 \mathrm{mg}$ of tablet Ivermectin along with other ongoing medications. His sputum culture showed profuse growth of Enterobacter spp and no acid fast bacilli were seen in microscopic examination. His antibiotics were changed according to his sensitivity profile (Table 1 ).

\begin{tabular}{cc} 
TABLE: 1 ANTIBIOTIC SENSITIVITY OF ENTEROBACTER SPP \\
\cline { 1 - 2 } AMOXYCLAV & $\mathrm{R}$ \\
CEFTRIAXONE & $\mathrm{R}$ \\
CEPHRADINE & $\mathrm{R}$ \\
AMIKACIN & $\mathrm{S}$ \\
CIPROFLOXACIN & $\mathrm{R}$ \\
CO-TRIMOXAZOLE & $\mathrm{R}$ \\
CEFTAZIDIME & $\mathrm{R}$ \\
IMIPENEM & $\mathrm{S}$ \\
GENTAMYCIN & $\mathrm{S}$ \\
MECILLINAM & $\mathrm{S}$ \\
NALIDXIC ACID & $\mathrm{R}$ \\
CEFUROXIME & $\mathrm{R}$ \\
MEROPENEM & $\mathrm{S}$ \\
NETILMICIN & $\mathrm{S}$ \\
AZTREONAM & $\mathrm{R}$ \\
\hline
\end{tabular}

2 days later his condition deteoriated, he became hypoxic with a saturation of $77 \%$ with 14 liter of oxygen per minute and was transferred to the Intensive Care Unit (ICU). Some of his investigations were repated showing $\mathrm{Hb}-10.10 \mathrm{~g} / \mathrm{dl}$, Total count of WBC $15.40 \times 109 / \mathrm{L}$ (neutrophilic leukocytosis), low Albumin level $(25.5 \mathrm{~g} / \mathrm{L})$. His repeat Xray showed slight shifting of trachea to the right side with patchy opacity involving both lungs showing a cavitary lesion in the right upper zone with air-fluid level (Fig. 2).

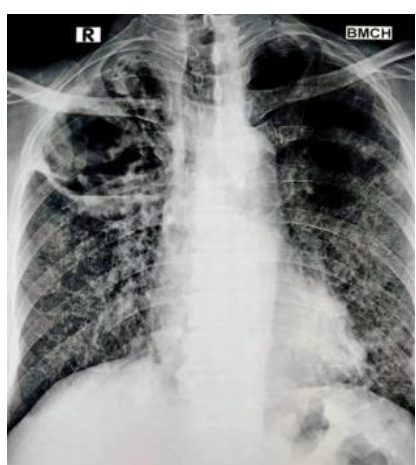

Fig. 2. Air- fluid level in right lung.

Following ongoing treatment his saturation improved i.e. 98-99\% with 10 litres of oxygen and he was also given 1 unit of convalescence plasma as plasma therapy for COVID-19. Due to cavitary leison we sent his sputum 
sample for GeneX-pert which came positive for Mycobacteruim tuberculosis without any resistance to Rifampicin. According to this anti TB medications were added to his treatment regimen. His condition improved gradually that's why he shifted to the isolated room but he developed bed sores on his left buttocks for which appropriate treatment was given. Both of his HIV $1 \& 2$ antibody test were negative. As his sputum amount did not improve so a repeat $\mathrm{X}$ ray was done showing patchy opacity on both lungs especially the right lung and an increased size of the cavitary lesion which was previously present (Fig. 3).

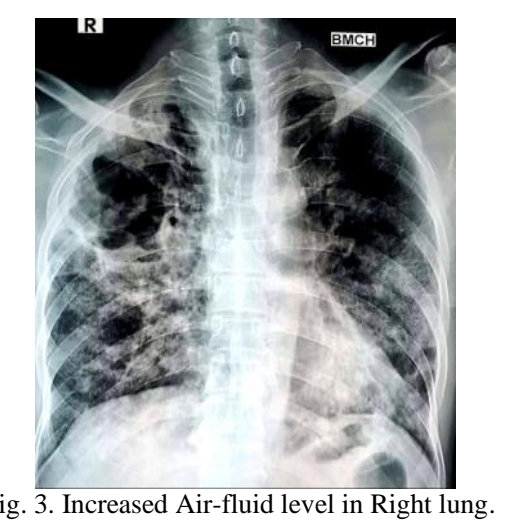

A repeat sputum culture was done showing profuse growth of Pseudomonas spp. this time. His antibiotics sensitivity profile was given in Table 2 and modifications of antibiotics were done accordingly.

\begin{tabular}{cc} 
TABLE 2: ANTIBIOTIC SENSITIVITY OF PSEUDOMONAS SPP \\
\cline { 2 - 2 } CEFTRIAXONE & $\mathrm{R}$ \\
AMIKACIN & $\mathrm{S}$ \\
CIPROFLOXACIN & $\mathrm{S}$ \\
CEFTAZIDIME & $\mathrm{S}$ \\
IMIPENEM & $\mathrm{R}$ \\
GENTAMYCIN & $\mathrm{R}$ \\
CEFUROXIME & $\mathrm{R}$ \\
PIPERACILLIN & $\mathrm{S}$ \\
MEROPENEM & $\mathrm{R}$ \\
NETILMICIN & $\mathrm{R}$ \\
AZTREONAM & $\mathrm{S}$ \\
COLISTIN & $\mathrm{R}$ \\
\hline
\end{tabular}

14 days of following ongoing treatment his RT-PCR test for COVID-19 came negative and his overall well-being improved a lot. Significant improvement was also found on his subsequent $X$ rays (Fig. 4) along with his further sputum culture showed no growth. He was discharged 6 weeks later and advised for routine follow-up.

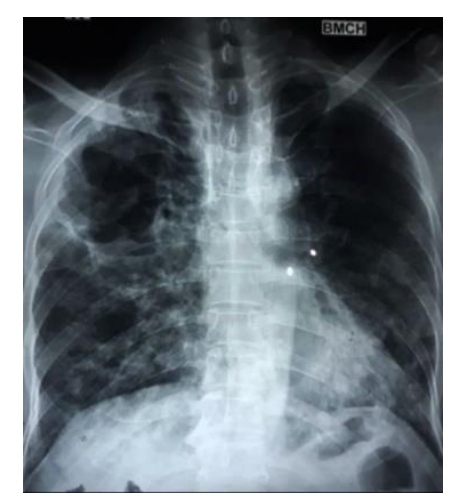

Fig. 4. Improved X-ray following treatment.

\section{DISCUSSION}

As a developing nation Bangladesh is always considered as an overcrowded country with an undernourished population. Thus, spreading of both TB and COVID-19 are much more expected here [9], [10]. The patient was a confirmed case of COVID-19 by his RT-PCR report which is a type of Nucleic Acid Amplification Test [11]. Coinfection with Mycobacterium tuberculosis was confirmed by Gene X-pert. This is a case of smear negative TB as his sputum smear showed no acid fast bacilli [12], [13]. Enterobacter spp and Pseudomonas were also confirmed by microbiological culture and sensitivity of sputum samples [14]. Enterobacter spp. can cause a wide variety of nosocomial infections, including those affecting the lungs, urinary tract, intra-abdominal cavity, and intravascular devices most of which are nosocomial [15], [16]. As Pseudomonas is also a nosocomial infection so there is a chance that he may have acquired it from the hospital during his stay as it was absent in his earlier sputum cultures. Cross transmission of Pseudomonas from person to person through hands of nursing staff appears to be a vital factor in the epidemiology of the infection [17]. Nosocomial infection could be endogenous infection or cross-infection [18]. Studies showing the relationship between COVID-19 and bacterial co-infection appear to be scarce. However, co-infection with bacteria or fungus was found around $8 \%$ of COVID-19 cases in one study [19]. While another study shows that it could be up to $50 \%$ in non-survivors. Co-pathogens included bacteria, such as Streptococcus pneumoniae, Staphylococcus aureus, Klebsiella pneumoniae, Mycoplasma pneumoniae, Chalmydia, pneumonia, Legionella pneumophila and Acinetobacter baumannii flavus; and viruses such as influenza, coronavirus, rhinovirus/enterovirus, parainfluenza, metapneumovirus, influenza B virus, and human immunodeficiency virus [20]. Diagnosing coinfection is complex as the presenting symptoms in COVID-19 infection and infection by other respiratory pathogens are similar. Other respiratory pathogens include all types of respiratory viral infections, atypical organisms and bacterial pathogens [21]. Also, the patient might have been carrying the organism before being infected with the virus or it may be a nosocomial infection or it might be part of an underlying chronic infection. Early diagnosis of coinfection is necessary, preferably using methods capable of detecting a broad range of potential pathogens and antimicrobial resistances, with subsequent monitoring of development of infections [22]. The case presented here is rare, as this patient is co-infected with not just one, but three bacterial pathogens which were confirmed by his sputum samples. The source by which the pathogens were acquired remains unclear. In this case, antibiotics were started from the time of his admission and were again changed according to his culture sensitivity results. Whether these drugs gave protection from further respiratory compromise or multi-organ involvement despite COVID-19 infection is unclear and should be explored further. Economical, medical and public health infrasturcture of all over the world has been challenged by the outbreak of this new virus. Time alone will tell how this virus will affect our lives in a developing country like Bangladesh. 


\section{CONCLUSION}

The case highlights the fact that the possibility of coinfection with other respiratory pathogens when diagnosing COVID-19 infection cannot be ruled out. Similarly, COVID-19 infection cannot be ruled out by detecting other respiratory pathogens. Therefore, testing for COVID-19 and other respiratory pathogens should be carried out simultaneously. Nosocomial or hospital acquired pneumonia is another concern for patients with longer hospital stays. To prevent nosocomial infection and to reduce morbidity, mortality and cost of hospital stay strict enforcement of hand hygiene and infection control measures should be taken. Further studies are needed in order to explore the risk factors, outcomes, management and prognosis of cases with COVID-19 and co-infection with other bacterial pathogens.

\section{ACKNOWLEDGEMENT}

I have taken efforts in this case report. However, it would not have been possible without the kind support and help of many individuals. My thanks and appreciation go to those people who are directly and indirectly helped us out in developing the case report.

\section{REFERENCES}

[1] World Health Organization, "Covid-19 Situation Report: 192," 30 July 2020. [Online]. Available: https://www.who.int/docs/defaultsource/coronaviruse/situation-reports/20200730-covid-19-sitrep192.pdf?sfvrsn=5e52901f_4.

[2] Yang X, Yu Y, Xu J, Shu H (2020). Clinical course and outcomes of critically ill patients with SARS-CoV-2 pneumonia in Wuhan, China: a single-centered, retrospective, observational study. The Lancet. Available: https://doi.org/10.1016/S2213-2600(20)30079-5

[3] Cui J, Li F, Shi ZL. (2019) Origin and evolution of pathogenic coronaviruses. Nat Rev Microbiol. 17(3):181-192. doi:10.1038/s41579-018-0118-9.

[4] World Health Organization. Infection prevention and control of epidemic- and pandemic-prone acute respiratory infections in health care. Geneva: World Health Organization; 2014 Available from: https://apps.who.int/iris/bitstream/handle/10665/112656/9789241507 134_eng.pdf?sequence $=1$.

[5] Ong SW, Tan YK, Chia PY, Lee TH, Ng OT, Wong MS, et al. Air, surface environmental, and personal protective equipment contamination by severe acute respiratory syndrome coronavirus 2 (SARS-CoV-2) from a symptomatic patient. JAMA. 2020 Mar 4 [Epub ahead of print].

[6] Zhang Y, Chen C, Zhu S et al. [Isolation of 2019-nCoV from a stool specimen of a laboratory-confirmed case of the coronavirus disease 2019 (COVID-19)]. China CDC Weekly. 2020;2(8):123-4. (In Chinese).

[7] J. F.-W. Chan, S. Yuan, K.-H. Kok, K. K.-W. To, H. Chu and J. Yang, "A familial cluster of pneumonia associated with the 2019 novel coronavirus indicating person-to-person transmission: a study of a family cluster. The Lancet. [Online]. Available: https://www.thelancet.com/journals/lancet/article/PIIS01406736(20)30154-9/fulltext.

[8] Rice TW, Rubinson L, Uyeki TM, et al. Critical illness from 2009 pandemic influenza A virus and bacterial coinfection in the United $\begin{array}{llll}\text { States. Crit Care } \quad \text { Med. 2012;40(5):1487-1498. } & \text { Care }\end{array}$ doi:10.1097/CCM.0b013e3182416f23

[9] J. Cohen, W. Powderly and S. Opal, Infectious Disease (Fourth Edition), Elsevier, 2016.

[10] Patel, J. A., Nielsen, F., Badiani, A. A., Assi, S., Unadkat, V. A., Patel, B., Ravindrane, R., \& Wardle, H. (2020). Poverty, inequality and COVID-19: the forgotten vulnerable. Public health, 183, 110111.

[11] World Health Organization, Laboratory testing for coronavirus disease, March 2020.
[12] Nakiyingi, L., Nankabirwa, H., \& Lamorde, M. (2013). Tuberculosis diagnosis in resource-limited settings: Clinical use of GeneXpert in the diagnosis of smear-negative PTB: a case report. African health sciences, 13(2), 522-524.

[13] Abong, J., Dalay, V., Langley, I., Tomeny, E., Marcelo, D., Mendoza, V., Aquino, A. C., Garfin, A., Squire, B., \& Yu, C. (2019). Use of GeneXpert and the role of an expert panel in improving clinical diagnosis of smear-negative tuberculosis cases. PloS one, 14(12), $\mathrm{e} 0227093$.

[14] K. C. C. J. B. a. S. M. Geo. Brooks, Jawetz, Melnick \& Adelbergs Medical Microbiology, Lange.

[15] Karnad, A., Alvarez, S., \& Berk, S. L. (1987). Enterobacter pneumonia. Southern medical journal, 80(5), 601-604.

[16] M. V. Villegas and J. P. Quinn, "Enterobacter species," [Online] Available:

http://www.antimicrobe.org/b97.asp\#: :text=Like\%20other\%20enter ic\%20gram\%2Dnegative, meningitis\%20(4\%2C\%2039).

[17] Dwivedi, M; Mishra, A; Singh, RK; Azim, A; Baronia, AK; Prasad, KN (2009). Nosocomial cross-transmission of Pseudomonas aeruginosa between patients in a tertiary intensive care unit. Indian Journal of Pathology and Microbiology.

[18] World Health Organization, "Hospital Hygiene \& Infection Control," [Online]. Available: https://www.who.int/docstore/water_sanitation_health/wastemanag/c h16.htm\#b3-

14.3.\%20The \%20prevention $\% 20$ of\%20nosocomial\%20infection.

[19] R. TM, M. LSP, Z. N, R. N, S. K, G. M, S. G, C. G and H. A. (2020). Bacterial and Fungal Coinfection in Individuals with Coronavirus: A Rapid Review to Support COVID-19 Antimicrobial Prescribing. [Online]. Available: https://academic.oup.com/cid/article/doi/10.1093/cid/ciaa530/582805 8.

[20] Chih-Cheng Lai, Cheng-Yi Wang, Po-Ren Hsueh. (2020) Coinfections among patients with COVID-19: The need for combination therapy with non-anti-SARS-CoV-2 agents. Journal of Microbiology, Immunology and Infection. ISSN 1684-1182.

[21] Singhal T. (2020). A Review of Coronavirus Disease-2019 (COVID19). Indian journal of pediatrics, 87(4), 281-286.

[22] Cox MJ; Loman N; Bogaert D; O'Grady J. (2020) Co-infections: potentially lethal and unexplored in COVID-19. The Lancet. https://doi.org/10.1016/S2666-5247(20)30009-4. 